\title{
Юбилеи
}

УДК 781.7(092)

\author{
И. В. Пчеловодова, А. В. Камитова \\ с МУзыкой по жизни! \\ (К ЮБИЛЕЮ И. М. НУРИЕВОЙ)
}

\begin{abstract}
Статья посвящена юбилею этномузыковеда, заслуженного деятеля науки, доктора искусствоведения Ирины Муртазовны Нуриевой. Рассматривается ее научная и творческая деятельность, анализируется вклад в изучение удмуртской музыкально-песенной традиции. За период работы в УИИЯЛ УдмФИЦ УрО РАН И. М. Нуриева опубликовала 5 монографий и более 100 статей. Ее труды востребованы не только среди академического сообщества и преподавателей высшей школы, но и всеми, кто интересуется народной культурой. Установлено, что высокий рейтинг популярности ее исследований достигнут в том числе благодаря вовлечению богатого материала полевых практик, в которых она принимает самое непосредственное участие: ею проведено большое количество экспедиций (фольклорно-диалектологических, фольклорно-этнографических, фольклорно-хореографических), география которых, помимо Удмуртской Республики, охватывает Республики Татарстан и Марий Эл, а также Кировскую область. Имя удмуртского этномузыковеда известно не только в российском масштабе, но и за его пределами. И. М. Нуриева - неоднократный участник международных конференций, конгрессов.
\end{abstract}

Ключевые слова: этномузыковедение, фольклор, юбилей, И. М. Нуриева, удмуртская музыкально-песенная традиция.

DOI: $10.35634 / 2224-9443-2019-13-4-718-721$

Имя этномузыковеда Ирины Муртазовны Нуриевой известно не только в Удмуртской Республике и в России, но и за рубежом. Доктор искусствоведения, заслуженный деятель науки (2016), ведущий научный сотрудник Удмуртского института истории, языка и литературы УдмФИЦ УрО РАН, ученый с 32-летним стажем работы, всю свою творческую энергию отдает исследованию удмуртской музыкально-песенной традиции. Сегодня трудно представить отечественную музыкальную фольклористику без ее научных трудов.

Родилась Ирина Муртазовна в немецком городке Ютерборг, в семье военнослужащего. Тогда никто не мог и предположить, что ее судьба крепко свяжется с Удмуртией. По окончании музыкальной школы, 15-летняя Ирина поступает на теоретическое отделение Мурманского музыкального училища. До сих пор с большой теплотой и любовью Ирина Муртазовна вспоминает те годы, а особенно - преподавателей, создавших базу для ее дальнейших творческих и научных достижений. Интерес к традиционной культуре удмуртов проявился во время учебы на теоретико-композиторском факультете в Казанской государственной консерватории, которую она окончила в 1987 году.

В Удмуртском институте истории, языка и литературы с 1987 г. И. М. Нуриева прошла путь от должности старшего лаборанта до ведущего научного сотрудника, неоднократно работала заведующей отделом фольклора и литературы. За всю ее трудовую биографию награждена разного рода грамотами и благодарственными письмами, в том числе - Почетной грамотой Удмуртской Республики (2009), Почетной грамотой Российской академии наук и Профсоюза работников РАН (2014).

За период работы в УИИЯЛ УрО РАН И. М. Нуриева опубликовала несколько монографий и множество статей, посвященных традиционной удмуртской музыке. Ее работы всегда востребованы не только среди академического сообщества и преподавателей высшей школы, но и всеми, кто интересуется народной культурой. Высокий рейтинг популярности ее трудов достигается и благодаря вовлечению богатого материала полевых практик, в которых она по-прежнему принимает самое непосредственное участие. Собирательская деятельность Ирины Муртазовны началась с первых же дней ее работы в Институте. Ею проведено большое количество экспедиций, география которых не ограничивается Удмуртской Республикой. Одиночные и коллективные фольклорно-диалектологические, фольклорноэтнографические, фольклорно-хореографические поездки были совершены ею в Республики Татарстан 
и Марий Эл, а также в Кировскую область. Ирина Муртазовна всегда болеет душой за сохранность ценных и уникальных образцов музыкального, языкового и этнографического материала народов Волго-Камья, хранящегося в звуковой лаборатории УИИЯЛ УдмФИЦ УрО РАН. Вопрос о востребованности материалов фонофонда Института и об их сохранности неоднократно поднимался ею в научных обсуждениях ${ }^{1}$. А полевые записи И. М. Нуриевой послужили основой для выпуска нескольких сборников из серий: «Памятники культуры. Фольклорное наследие», «Удмуртский фольклор» ${ }^{2}$. Публикация песенных томов получила глубокое научное осмысление в ее монографии «Музыка в обрядовой культуре завятских удмуртов: проблемы культурного контекста и традииионного мылиления» (1999).

Богатый материал песенного фольклора, собранный И. М. Нуриевой во время многолетних экспедиций, стал надежной фактологической основой ее диссертационных работ. Так, в 2000 году в Российском институте истории искусств (г. Санкт-Петербург) Ирина Муртазовна успешно защищает кандидатскую диссертацию по музыкальной культуре завятских удмуртов. Собранные автором полевые музыкально-фольклорные и этнографические материалы, послужившие основным источником исследования, позволили представить целостную характеристику песенной традиции завятских удмуртов на уровне системы жанров, поэтики, исполнительского контекста, музыкального стиля (ритмики, ладовых форм).

В 2015 году И. М. Нуриева блестяще защищает докторскую диссертацию по теме «Удмуртская музыкально-песенная традиция: специфика жанрообразования и функционирования» на соискание ученой степени доктора искусствоведения в центральном исследовательском учреждении страны Государственном институте искусствознания (г. Москва). Эта работа стала первым комплексным исследованием удмуртской музыкально-песенной культуры как исторического и этнокультурного явления. Благодаря грамотному привлечению современных для этномузыковедения методологических подходов и введению в научный оборот полевых и архивных материалов ею были получены новые результаты в области песенно-музыкальной традиции удмуртов. Предложенная в ее исследовании концепция перспективна для изучения других этнических культур региона.

На основе докторской диссертации И. М. Нуриевой была подготовлена и опубликована в 2014 году монография «Импровизация в песенной культуре удмуртов: жсанр, стиль, мышление»". Малоизученный феномен удмуртской традиционной культуры - песенная импровизация - в данной работе изучен в контексте финно-угорской музыкальной традиции с вовлечением новых полевых материалов, зафиксированных автором в последние десятилетия.

\footnotetext{
${ }^{1}$ См., например, статью, получившую общественный резонанс: Нуриева И. М. Юбилейная дата: поговорим о... проблемах // Наука Удмуртии. 2006. № 2. С. 123-127.

${ }^{2}$ Издаваемые УИИЯЛ УдмФИЦ УрО РАН книги серии «Удмуртский фольклор» представляют собой серию нотных сборников, песенный материал в которых распределен по локальному принципу. К настоящему времени опубликовано восемь томов, в которых представлены обрядовые песни южных (алнашских, кукморских, кизнерских, шошминских, малопургинских) и северных (глазовских и кировских) удмуртов, а также отдельный том хороводных и игровых песен (см.: Бойкова Е. Б., Владыкина Т. Г. Песни южных удмуртов. Ижевск: УИИЯЛ УрО РАН, 1992. Вып 1. 192 с. (Удмуртский фольклор); Нуриева И. М. Песни завятских удмуртов. Ижевск: УИИЯЛ УрО РАН, 1995. Вып. 1. 232 с. (Удмуртский фольклор); Ходырева М. Г. Песни северных удмуртов. Ижевск: УИИЯЛ УрО РАН, 1996. Вып. 1. 120 с. (Удмуртский фольклор); Чуракова Р. А. Песни южных удмуртов. Ижевск: УИИЯЛ УрО РАН, 1999. Вып 2. 160 с. (Удмуртский фольклор); Хороводно-игровые и плясовые песни / сост. Долганова Л. Н. Ижевск: УИИЯЛ УрО РАН, 1999. 120 с. (Удмуртский фольклор); Нуриева И. М. Песни завятских удмуртов. Ижевск: УИИЯЛ УрО РАН, 2004. Вып. 2. 332 с. (Удмуртский фольклор); Пчеловодова И. В., Анисимов Н. В. Песни южных удмуртов. Ижевск-Тарту, 2015. Вып. 4. - 374 с. (Удмуртский фольклор). О ценности и необходимости этих серий сама И. М. Нуриева пишет следующим образом: «Тома антологии «Удмуртский фольклор» содержат уникальный материал по обрядовой культуре удмуртов. Публикация антологии важна и своевременна не только потому, что остались зафиксированными архаичные, уже исчезающие из активного репертуара напевы. Хотя собрана и опубликована еще малая часть всего материала, благодаря этой серии более рельефно обозначились специфические черты музыкального и поэтического языка удмуртской песенной культуры, особенности жанровых систем, в частности, жанров календарного цикла. Материалы антологии - песенная терминология, жанры, ладовые и ритмические формулы, наконец, непосредственно напевы - являются ценнейшими источниками для будущего картографирования и создания единого музыкального атласа» (См.: Нуриева И. М. Удмуртская музыкально-песенная традиция: специфика жанрообразования и функционирования: дис. ... докт. искусствоведения / Удмурт. гос. ун-т. Ижевск, 2014. С. 48-49).

${ }^{3}$ Нуриева И. М. Импровизация в песенной культуре удмуртов: жанр, стиль, мышление / Российская акад. наук, Уральское отд-ние, Удмуртский ин-т истории, языка и литературы. Ижевск: Удмуртский ин-т истории, языка и литературы, 2014. 110 с.
} 
Одна из последних монографий И. М. Нуриевой «Музыкальный язык удмуртского ритуала: Время. Пространство. Текст» ${ }^{4}$ представляет собой новый опыт осмысления накопленного песенного материала за последние десятилетия. Эта фундаментальная работа посвящена описанию звукового ландшафта в контексте исторического и сакрального времени и пространства.

Другим направлением научно-музыкального наследия И. М. Нуриевой стала традиционная инструментальная музыка, которая до сих пор остается малоизученной областью удмуртского этномузыковедения. Она - первый этномузыковед, комплексно исследовавший инструментальную культуру шошминских удмуртов, осветив вопросы функционирования, морфологических особенностей, процессов изготовления таких инструментов, как кубыз (народная скрипка), крезь (гусли), домбро (струнный варган). В ее трудах впервые затронута проблема роли музыканта в традиционной культуре удмуртов ${ }^{5}$.

И. М. Нуриева всегда открыта научному диалогу в самых разных формах и сферах. Так, например, в 1991 г. она проходит научную стажировку в Литературном музее им. Ф. П. Крейцвальда АН Эстонии, а в 1996 г. - в Центре Мировой музыки (Хельсинки). Прочные международные связи она сохраняет и по настоящее время. Во время научных зарубежных командировок она всегда востребована как лектор. Ее лекции отличаются уникальностью материала, сопровождаемой наглядными аудио- и видеопримерами, с научной фактологической основой и при этом - легкостью подачи материала, что важно для восприятии аудиторией. Результатом сотрудничества с Центром Мировой музыки (Хельсинки) стал выпуск музыкального диска «Инвожо» (2007), включающего музыкальные образцы локальных особенностей удмуртского песенного фольклора.

И. М. Нуриева - член диссертационного совета по специальности 17.00.02 - Музыкальное искусство, действующего в Казанской государственной консерватории имени Н. Г. Жиганова. Будучи членом редакционной коллегии в ведущих научных журналах («Музыкальный журнал Европейского Севера», «Ежегодник финно-угорских исследований», «Финно-угорский мир»), она с большим вниманием относится к научным проблемам своих коллег, оказывая им высококвалифицированные советы, замечания, предложения. Ее широкие связи с учеными из других регионов позволяют издавать труды в ведущих научных академических издательствах. К примеру, одна из свежих работ - опубликованная в издательстве «Наука» коллективная монография «Звучащие ландшафты Арктики» ${ }^{6}$.

И. М. Нуриева успешно апробирует свои научные разработки в преподавательской практике. Помимо лекций по методике преподавания специальных дисциплин, теории фольклора, удмуртской музыке в Институте искусств и дизайна УдГУ, она активно участвует в создании и рецензировании учебно-методических пособий. В подготовленных ею пособиях для вузов по удмуртскому фольклору $^{7}$ задействованы полевые материалы фонограмархива УИИЯЛ УдмФИЦ УрО РАН, способствующие приобщению молодого поколения к традиции народной музыки.

Юбиляра характеризует широкий круг научных и общественных связей. Большого уважения и признания заслуживает активная деятельность Ирины Муртазовны в составлении и редактировании коллективных и индивидуальных трудов по вопросам удмуртской музыкальной традиции. Публикуемые ею статьи в ведущих российских и зарубежных научных журналах пользуются большой популярностью. И. М. Нуриева - постоянный участник международных, всесоюзных, всероссийских и региональных научных конференций, конгрессов и симпозиумов в России и за рубежом.

С большим вниманием относится она к научным проблемам своих коллег. Ее высококвалифицированные советы, замечания, предложения оказывают им неоценимую помощь в работе над научными трудами. Профессионализм и такие человеческие качества, как трудолюбие, доброта, чуткое отношение к людям - неотъемлемая черта И. М. Нуриевой.

\footnotetext{
${ }^{4}$ Нуриева И. М. Музыкальный язык удмуртского ритуала: Время. Пространство. Текст: Монография / УИИЯЛ УдмФИЦ УрО РАН. Ижевск: Изд-во «АлкиД», 2018. 157 с.

${ }^{5}$ Нуриева И. М. Кубыз / кубызчи в межнациональном контексте культур // Музыкант в культуре: концепции и деятельность. Сб. ст. СПб:РИИИ, 2005. С. 46-50.

${ }^{6}$ См.: Василенко О. В., Добжанская О. Э., Дьяконова В. Е., Игнатьева Т. И., Кардашевская Л. И., Мамчева Н. А., Никифорова В. С., Нуриева И. М., Пчеловодова И. В., Шейкин Ю. И. Звучащие ландшафты Арктики / Под общ. ред. О. Э. Добжанской, Т. И. Игнатьевой / Арктический государственный институт культуры и искусств; Удмуртский институт истории, языка и литературы УдмФИЦ УрО РАН; Киевская муниципальная академия музыки им. Р. М. Глиера; Сахалинский колледж искусств. Новосибирск: Наука, 2019. 172 с.

${ }^{7}$ Нуриева И. М. Многоголосие на уроках сольфеджио (на материале удмуртских народных песен): учебнометодическое пособие. Ижевск: УИИЯЛ УрО РАН, 2011.26 с.
} 
Дорогая Ирина Муртазовна! Мы, коллеги и друзья, от всей души поздравляем Вас с юбилеем! Желаем крепкого здоровья, неиссякаемой жизненной энергии, научного энтузиазма, душевной молодости и успехов в реализации новых идей и проектов!

Поступила в редакцию 30.09.2019

Пчеловодова Ирина Вячеславовна, кандидат филологических наук, научный сотрудник Удмуртский институт истории, языка и литературы Удмуртского федерального исследовательского центра УрО РАН 426004, Россия, г. Ижевск, ул. Ломоносова, 4 E-mail: orimush@mail.ru

Камитова Алевтина Васильевна, кандидат филологических наук, старший научный сотрудник Удмуртский институт истории, языка и литературы Удмуртского федерального исследовательского центра УрО РАН 426004, Россия, г. Ижевск, ул. Ломоносова, 4 E-mail: akamitova@mail.ru

\section{V. Pchelovodova, A. V. Kamitova WITH MUSIC THROUGH LIFE (TO THE ANNIVERSARY OF I. M. NURIEVA)}

DOI: $10.35634 / 2224-9443-2019-13-4-718-721$

The article is devoted to the anniversary of Irina Murtazovna Nurieva, the prominent ethnomusicologist, Honored scientist, Doctor of Art. The author focuses on her scientific and creative activity and analyzes her contribution to the study of the Udmurt musical and song tradition. During her period of work in the Udmurt Institute of History, Language and Literature UdmFRC UB RAS I. M. Nurieva published five monographs and more than a hundred articles. Her works are in demand not only among the academic community and teachers of higher education, but also of all those who are interested in folk culture. It was established that a high popularity rating of her research was achieved due to the involvement of the rich material from field practices in which she was directly involved During her activities she conducted a large number of expeditions (folklore-dialectological, folklore-ethnographic, folklore-choreographic), the geography of which, in addition to the Udmurt Republic, covers the Republic of Tatarstan, the Republic of Mari El, the Kirov region. The name of the Udmurt ethnomusicologist is known not only on a Russian scale, but also outside of it. I. M. Nurieva is a returning participant in international conferences, congresses.

Keywords: ethnomusicology, folklore, anniversary, I. M. Nurieva, Udmurt music and song tradition.

Citation: Yearbook of Finno-Ugric Studies, 2019, vol. 13, issue 4, pp. 718-721. In Russian.

Received 30.09.2019

Pchelovodova Irina Vyacheslavovna, Candidate of Philology, Research Associate Udmurt Institute of History, Language and Literature, UdmFRC UB RAS 4, ul. Lomonosova, Izhevsk, 426004, Russian Federation E-mail: orimush@mail.ru

Kamitova Alevtina Vasilievna, Candidate of Philology, Senior Research Associate Udmurt Institute of History, Language and Literature, UdmFRC UB RAS 4, ul. Lomonosova, Izhevsk, 426004, Russian Federation E-mail: akamitova@mail.ru 